\title{
Gestational diabetes: Current status
}

\author{
Mehmet Okan Özkaya, Seyit Ali Köse \\ Department of Obstetrics \& Gynecology, Faculty of Medicine, Siileyman Demirel University, Isparta, Turkey
}

\begin{abstract}
Gestational diabetes (GDM) is a glucose tolerance disorder which begins during pregnancy or diagnosed during pregnancy for the first time. Its prevalence increases day by day. The major reasons are the obesity incidence increasing globally and reducing threshold values in the diagnostic tests. The diagnosis and treatment of GDM is very significant since it may cause maternal and fetal complications. There are many risk factors of gestational diabetes. The major factors are GDM history and obesity. There has been still no exact approach for gestational diabetes screening.
\end{abstract}

Keywords: Gestational diabetes, screening.

\section{Introduction}

Gestational diabetes (GDM) is a glucose tolerance disorder which begins during pregnancy or diagnosed during pregnancy for the first time. ${ }^{[1,2]}$ While its prevalence varies in each society, its prevalence increases each passing day. The major reasons are the increasing obesity incidence and reducing threshold values of diagnostic tests. ${ }^{[3]}$ American Diabetes Association (ADA) reports that GDM is seen in about $4 \%$ of all pregnant women, which means 135,000 women per year. ${ }^{[4]}$ Although the prevalence of gestational diabetes varies according to ethnicity, it increases as the age increases. GDM prevalence in pregnants above 25 years old is 8-10 times higher than those below 25 years old. ${ }^{[5]}$

Hyperinsulinemia, insulin resistance, preprandial hypoglycemia and postprandial hypoglycemia are seen in normal pregnancies. ${ }^{[6]}$ The reason is the necessity to provide required glucose transfer to the fetus. Cortisol,

\section{Özet: Gestasyonel diyabet: Güncel durum}

Gestasyonel diyabet (GDM) gebelikte başlayan veya ilk kez gebelik sırasında tanı konulan glukoz tolerans bozukluğudur. Sıklı̆̆ı günümüzde giderek artmaktadır. Bunun en önemli nedenleri dünya çapında artan obezite insidansı ve tanı testlerindeki eşik değerlerin düşmesidir. Maternal ve fetal komplikasyonlara neden olabildiği için GDM'nin tanı ve tedavisi önemlidir. Gestasyonel diyabet için birçok risk faktörü vardır. Bunların en önemlileri GDM öyküsü ve obezitedir. Gestasyonel diyabet taraması için halen net bir yaklaşım yoktur.

Anahtar sözcükler: Gestasyonel diyabet, tarama.

growth hormone, estrogen, progesterone, prolactin secreted in placental medium during pregnancy and especially the increase of human placental lactogen are responsible for such physiological changes. As the week of gestation increases, this condition caused by placental hormones leads an increasing need for insulin. In order to meet this need, hypertrophy and hyperplasia develop in the pancreas. ${ }^{[6,7]}$ GDM appears when this adaptation in the pancreas during pregnancy cannot meet the insulin need. Insulin need increases about $40-70 \%$ in the last trimester. In a study conducted, it was found that glucose intake into peripheral muscle tissue in the last trimester was $40 \%$ lower in pregnant woman compared to non-pregnant women. ${ }^{[8]}$

Gestational diabetes was first defined by O'Sullivan and Mahan in 1964 by determining the criteria for oral glucose tolerance test. ${ }^{[9]}$ These criteria were revised by Carpenter and Coustan, American Diabetes Association and other national diabetes associations over the years. In

\footnotetext{
Correspondence: Mehmet Okan Özkaya, MD. Süleyman Demirel Üniversitesi Tıp Fakültesi Kadın Hastalıkları ve Doğum Anabilim Dalı, Isparta, Turkey. e-mail: drokanozkaya@yahoo.com
}

Received: January 27, 2014; Accepted: April 5, 2014
Available online at: www.perinataljournal.com/20140222012 doi: $10.2399 / \mathrm{prn} .14 .0222012$ QR (Quick Response) Code: 
Table 1. Complications which may develop associated with gestational diabetes (GDM) ${ }^{[6]}$

\begin{tabular}{lccc} 
Mother & Fetus & Newborn & Childhood/Adulthood \\
Delivery trauma & Hyperinsulinemia & Respiratory distress & Obesity \\
Cesarean rate $\uparrow$ & Cardiomyopathy & Hypoglycemia & Type 2 diabetes \\
Preeclampsia- Gestational HT & Stillbirth & Hypocalcemia - Hypomagnesemia & Metabolic syndrome \\
Type 2 diabetes & Macrosomia & Hyperbilirubinemia & \\
Metabolic syndrome & Birth trauma & Polycythemia & \\
\hline
\end{tabular}

HT: Hypertension.

2008, the results of HAPO (Hyperglisemia and Adverse Pregnancy Outcome) were published and new criteria became at the agenda based on the results of this study.

In 2010, ADA classified diabetes under 4 titles: $:^{[2]}$

- Type 1 diabetes

- Type 2 diabetes

- Gestational diabetes

- Other specific diabetes types

The diagnosis and treatment of gestational diabetes is significant since it may cause maternal and fetal complications. In the pregnants with gestational diabetes, gestational hypertension, preeclampsia, delivery by cesarean and other associated complications develop frequently. ${ }^{[3]}$ Also, approximately half of these women develop Type 2 diabetes within 22-28 years. ${ }^{[3]}$

The most significant factor here is the ethnicity and the presence of obesity. Fetal macrosomia, neonatal hypoglycemia, hyperbilirubinemia , shoulder dystocia, increase in operative delivery prevalence, and the delivery trauma are observed frequently in pregnant women with gestational diabetes. ${ }^{[3]}$ The impacts of GDM on mother, fetus, newborn, and childhood periods are shown in Table 1.

There are many risk factors for gestational diabetes. GDM history and obesity are the most significant risk factors of gestational diabetes. These risk factors are given in Table 2.

\section{Screening Methods in Gestational Diabetes}

There are some problems encountered during GDM screening in the world. Today, there has been still no consensus. While many associations and organizations use various screening/diagnostic tests, there are also differences in the threshold values of these tests. The threshold values of these tests used by various associations are given in Table 3.

There are 2 different approaches for gestational diabetes. While all pregnant women are screened during general screening, only the pregnant women in the risk group are screened in selective screening. During screening, one- and two-step methods may be used. WHO suggests one-step approach while many associations suggest two-step approach. One-step approach is based on $75 \mathrm{~g}$ oral glucose tolerance test (OGTT), but two-step approach is based on applying $50 \mathrm{~g}$ OGTT first and then $100 \mathrm{~g}$ OGTT.

In two-step approach, pregnant woman is given $50 \mathrm{~g}$ glucose regardless of her preprandial or postprandial condition, and then her blood sugar is checked 1 hour later. If the test result is found to be 130 or $140 \mathrm{mg} / \mathrm{dl}$ or above, $100 \mathrm{~g}$ OGTT is applied. There are some certain required conditions for $100 \mathrm{~g}$ glucose tolerance test. Pregnant woman should be hungry and the test should be applied in the morning, she should take at least $150 \mathrm{~g}$

Table 2. Risk factors in gestational diabetes. ${ }^{[6]}$

\begin{tabular}{lc} 
Risk factor & Risk increase rate \\
Overweight & $\times 2$ \\
Obesity & $\times 3.7$ \\
Severe obesity & $\times 7$ \\
Gestational diabetes history & $\times 23$ \\
History of delivering macrosomic fetus & $\times 3.3$ \\
Pregnancy over 25 years old & $\times 1.4$ \\
Pregnancy over 35 years old & $\times 2.3$ \\
Multiple pregnancy & $\times 2.2$ \\
Polycystic ovarian syndrome & $\times 2.9$ \\
Diabetes history in the family & $\times 3.2$ \\
\hline
\end{tabular}


Table 3. Threshold values of the associations for gestational diabetes. ${ }^{[10]}$

\begin{tabular}{|c|c|c|c|c|c|c|c|}
\hline Associations & Grade & Glucose (gram) & FBG (mg/dl) & 1-h & 2-h & 3-h & Number of increased value \\
\hline CC & 2 & 100 & 95 & 180 & 155 & 140 & 2 \\
\hline NDDG & 2 & 100 & 105 & 190 & 165 & 154 & 2 \\
\hline ADA & 2 & 75 & 95 & 180 & 155 & & 2 \\
\hline CDA & 2 & 75 & 95 & 191 & 160 & & 2 \\
\hline WHO (2013) & 1 & 75 & $92-125$ & 180 & 153-199 & & 1 \\
\hline IADPSG & 1 & 75 & 92 & 180 & 153 & & 1 \\
\hline
\end{tabular}

ADA: American Diabetes Association, FBG: Fasting blood glucose, CC: Carpenter-Coustan, CDA: Canada Diabetes Association, IADPSG: International Association of Diabetes and Pregnancy Study Group, NDDG: National Diabetes Data Group, WHO: World Health Organization.

carbohydrate daily for 3 days, pregnant woman should be in sitting position during the test and she should not smoke. If threshold value is considered to be $130 \mathrm{mg} / \mathrm{dl}$ in $50 \mathrm{~g}$ test, the rate to detect GDM is $95 \%$ while it is $80 \%$ if the threshold value is considered to be 140 $\mathrm{mg} / \mathrm{dl} .^{[11]}$

In the one-step approach, the required criteria to do $75 \mathrm{~g}$ OGTT is similar with $100 \mathrm{~g}$ test. In addition, fasting blood glucose (FBG), 1st hour and 2nd hour blood sugar levels are checked and if one value is found to be out of the limits, the test is considered as positive.

International Association of Diabetes and Pregnancy Study Group (IADPSG) is a group established in 1998 to unite the international groups working on diabetes and pregnancy. This group planned a study published in recent years and led the recommendation of new threshold values. This study, called HAPO, was carried on 25,505 pregnant women as a prospective, blind, international and multi-centered (9 countries and 15 centers) study. In the study, the results of 23,316 patients were reviewed and these results were evaluated in terms of the relationship between gestational outcomes and the increase in each glucose level with standard deviation. In the study, primary outcomes such as macrosomia, primary cesarean delivery, and clinical neonatal hypo-

Table 4. $75 \mathrm{~g}$ OGTT threshold values of IADPSG workshop (mg/dl).

\begin{tabular}{cccc} 
& FBG & 1-h & 2-h \\
$75 \mathrm{~g} \mathrm{OGTT}$ & $92^{*}$ & $180^{*}$ & $153^{*}$ \\
\hline
\end{tabular}

FBG: Fasting blood glucose. glycemia and C-peptide (the indicator of fetal insulin level) level in cord blood being higher than 90th percentile, and secondary outcomes such as preeclampsia, premature labor, shoulder dystocia, hyperbilirubinemia and newborn's intense care need were evaluated. In the study, it was found that the primary cesarean rate, the prevalence of birth weight being higher than 90th percentile and the prevalence of clinical neonatal hypoglycemia were increased with the increasing glucose level. No special threshold value was calculated in the study for risk increase. Also, no superiority between preprandial and postprandial blood glucose was observed in the study for the anticipation of perinatal risk increase. ${ }^{[12]}$

IADPSG organized a workshop in 2010 in order to evaluate the results of HAPO study and to determine an internationally recognized screening/diagnostic test and appropriate threshold values. ${ }^{[13]}$ In this workshop, it was suggested to do one-step $75 \mathrm{~g}$ OGTT for today, consider test threshold values as $\mathrm{FBG} \geq 92 \mathrm{mg} / \mathrm{dl}$, 1st hour blood glucose $\geq 180 \mathrm{mg} / \mathrm{dl}$ and 2 nd hour blood glucose $\geq 153 \mathrm{mg} / \mathrm{dl}$ and to establish GDM diagnosis if any of them is out of the limits.

For the diagnosis of overt diabetes, it was suggested in the workshop of IADPSG that threshold value should

Table 5. Overt diabetes threshold values of IADPSG workshop (mg/dl).

\begin{tabular}{cccc} 
& FBG & HbA1c & Random BG* \\
Overt diabetes & $\geq 126^{*}$ & $\geq \% 6.5$ & $\geq 200$ \\
\hline
\end{tabular}

FBG: Fasting blood glucose. *In this case, the test should be confirmed by FBG and/or HbA1c. 
All pregnant women should be evaluated in the first prenatal examination.

Fasting blood glucose (FBG), HbA1c or random blood glucose (RBG) test should be requested.

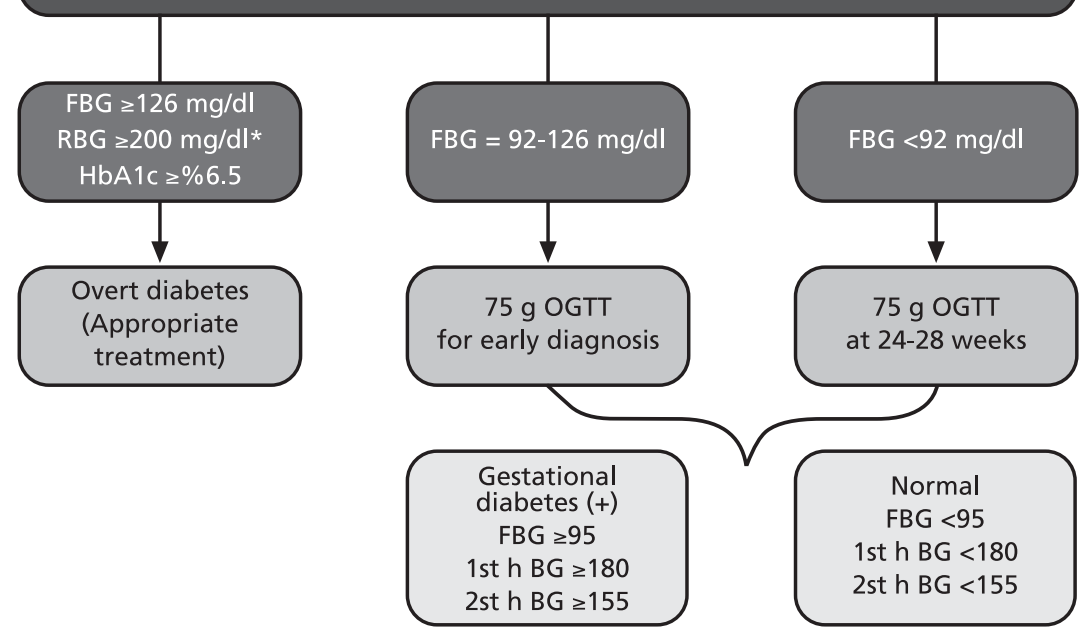

*The diagnosis should be confirmed by FBG or HbA1C.

Fig. 1. Screening pregnant women in terms of GDM.

be $\geq 126 \mathrm{mg} / \mathrm{dl}$ for FBG, $6.5 \%$ for $\mathrm{HbAlc}$ and $\geq 200$ $\mathrm{mg} / \mathrm{dl}$ for random blood sugar (in this case, it should be confirmed by FBG and HbA1c). The workshop results of IADPSG are summarized in Tables $\mathbf{4}$ and $\mathbf{5}$.

However, if the threshold values recommended by IADPSG are used, GMD prevalence increases and cost/benefit ratio collapses. Today, in the studies which research the suitability of using the thresholds recommended by IADPSG, it was reported that the pregnancy prognoses of the patients who were normal according to previous threshold values but considered to be GDM according to IADPSG's threshold values were similar to those who were not GDM, and that using the threshold values of IADPSG increased the costs. ${ }^{[14-17]}$

For today, more studies are needed for determining the necessity of using IADPSG's threshold values.

\section{Treatment Results}

By the treatment of pregnant women with gestational diabetes, both maternal and fetal complications decrease distinctly. The related study of Crowther et al. carried out in 2005 found that perinatal mortality, shoulder dystocia and birth trauma reduced by the treatment. In this study, it was also seen that the rate of delivering baby over $4000 \mathrm{~g}$ decreased from $21 \%$ to $10 \%$, and preeclampsia decreased from $18 \%$ to $12 \% .{ }^{[18]}$

In another study which was multi-centered and carried out in 2009, it was reported that no distinct change was observed in the primary outcomes of the treatments of 958 cases with mild GDM. However, the rate of cesarean, shoulder dystocia and hypertensive disorders decreased by the treatment. ${ }^{[19]}$

\section{Conclusion}

Consequently, GDM prevalence today increases day by day. Associated with GDM, maternal and perinatal complication rates also increase. There has been no consensus on the screening/diagnostic tests and applications of GDM in the world yet and even the threshold values vary among the associations. For today, there is no sufficient data to for decreasing the threshold values of 75 g OGTT recommended by IADPSG and using these values in the routine. In addition, these recommended approaches increase the prevalence and cost of GDM.

In brief, it seems appropriate to screen all pregnant women in the first trimester in terms of FBG or HbA1c or random blood glucose and to screen all pregnants, 
who were not observed to have overt diabetes or GDM, at 24-28 weeks of gestation by $75 \mathrm{~g}$ OGTT. Fig. 1 summarizes this. Until the studies on the criteria of IADPSG are clarified, we believe that it would be convenient to consider the threshold of FBG as $\geq 95 \mathrm{mg} / \mathrm{dl}$, the threshold of first hour blood glucose as $\geq 180 \mathrm{mg} / \mathrm{dl}$, and the threshold of second hour blood glucose as $\geq 155 \mathrm{mg} / \mathrm{dl}$. If any of these values is out of the limits, GDM diagnosis should be established. Also, if during the test the FBG or first hour blood glucose seem is out of the limits, the test should be considered as positive and the test should be terminated.

Conflicts of Interest: No conflicts declared.

\section{References}

1. National Diabetes Data Group. Classification and diagnosis of diabetes and other categories of glucose intolerance. Diabetes 1979;28:1039-57.

2. American Diabetes Association. Diagnosis and classification of diabetes mellitus. Diabetes Care 2011;34(Suppl 1):S62S69.

3. The American College of Obstetricians and Gynocologists. Gestational diabetes mellitus. Practice Bullletin 2013;122: 406-16.

4. Karakurt F, Çarlığlu A, Kasapoğlu B,Gümüş İI. Gestasyonel diabetes mellitus tanı ve tedavisi. Yeni Tip Dergisi 2009;26: 134-8.

5. Marquette GP, Klein VR, Niebyl JR. Efficacy of screening for gestational diabetes. Am J Perinatol 1985;2:7-9.

6. Pridjian G, Benjamin TD. Update on gestational diabetes. Obstet Gynecol Clin North Am 2010;37:255-67.

7. Van Assche FA, Aerts L, De Prins F. A morphological study of the endocrine pancreas in human pregnancy. Br J Obstet Gynaecol 1978;85:818-20.

8. Sivan E, Chen X, Homko CJ, Reece EA, Boden G. Longitudinal study of carbohydrate metabolism in healthy obese pregnant women. Diabetes Care 1997;20:1470-5.

9. Cheung KW, Wong SF. Gestational diabetes mellitus update and review of literature. Reprod Syst Sex Disord 2012;S2: 002 .

10. Donovan L, Hartling L, Muise M, Guthrie A, Vandermeer B, Dryden DM. Screening tests for gestational diabetes: a systematic review for the U.S. Preventive Services Task Force. Ann Intern Med 2013;159:115-22.

11. American Diabetes Association. Standards of medical care in diabetes-2013. Diabetes Care 2013;36(Supp 1):S11-S66.

12. HAPO Study Cooperative Research Group; Metzger BE, Lowe LP, Dyer AR, Trimble ER, Chaovarindr U, Coustan DR, et al. Hyperglycemia and adverse pregnancy outcomes. N Engl J Med 2008;358:1991-2002.

13. International Association of Diabetes and Pregnancy Study Groups Consensus Panel; Metzger BE, Gabbe SG, Persson B, Buchanan TA, Catalano PA, Damm P, et al. International Association of Diabetes and Pregnancy Study Groups recommendations on the diagnosis and classification of hyperglycemia in pregnancy. Diabetes Care 2010;33:676-82.

14. Bodmer-Roy S, Morin L, Cousineau J, Rey E. Pregnancy outcomes in women with and without gestational diabetes mellitus according to the International Association of the Diabetes and Pregnancy Study Groups criteria. Obstet Gynecol 2012;4:746-52.

15. Wendland EM, Torloni MR, Falavigna M, Trujillo J, Dode MA, Campos MA, et al. Gestational diabetes and pregnancy outcomes--a systematic review of the World Health Organization (WHO) and the International Association of Diabetes in Pregnancy Study Groups (IADPSG) diagnostic criteria. BMC Pregnancy Childbirth 2012;31:12-23.

16. Falavigna M, Prestes I, Schmidt MI, Duncan BB, Colagiuri S, Roglic G. Impact of gestational diabetes mellitus screening strategies on perinatal outcomes: a simulation study. Diabetes Res Clin Pract 2013;3:358-65.

17. Werner EF, Pettker CM, Zuckerwise L, Reel M, Funai EF, Henderson J, et al. Screening for gestational diabetes mellitus: are the criteria proposed by the international association of the Diabetes and Pregnancy Study Groups cost-effective? Diabetes Care 2012;35:529-35.

18. Crowther CA, Hiller JE, Moss JR, McPhee AJ, Jeffries WS, Robinson JS; Australian Carbohydrate Intolerance Study in Pregnant Women (ACHOIS) Trial Group. Effect of treatment of gestational diabetes mellitus on pregnancy outcomes. N Engl J Med 2005;24:2477-86.

19. Landon MB, Spong CY, Thom E, Carpenter MW, Ramin SM, Casey B, et al.; Eunice Kennedy Shriver National Institute of Child Health and Human Development Maternal-Fetal Medicine Units Network. A multicenter, randomized trial of treatment for mild gestational diabetes. $\mathrm{N}$ Engl J Med 2009;361:1339-48. 